\title{
Optimization of extrusion process to obtain shrimp snacks with rice grits and polished rice grains
}

\section{Lúcia F. H. Lourenço, Tiago S. Tavares, Eder A. F. Araujo, Rosinelson S. Pena,} Maria Regina S. Peixoto Joele \& Ana Vânia Carvalho

To cite this article: Lúcia F. H. Lourenço, Tiago S. Tavares, Eder A. F. Araujo, Rosinelson S. Pena, Maria Regina S. Peixoto Joele \& Ana Vânia Carvalho (2016) Optimization of extrusion process to obtain shrimp snacks with rice grits and polished rice grains, CyTA - Journal of Food, 14:2, 340-348, DOI: 10.1080/19476337.2015.1114025

To link to this article: http://dx.doi.org/10.1080/19476337.2015.1114025

$$
\begin{aligned}
& \text { (c) } 2015 \text { The Author(s). Published by Taylor \& } \\
& \text { Francis. }
\end{aligned}
$$

\section{曲 Published online: 23 Nov 2015.}

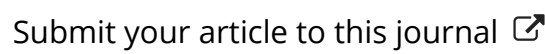

Џ Article views: 216

Q View related articles 두

View Crossmark data $\nearrow$ 


\title{
Optimization of extrusion process to obtain shrimp snacks with rice grits and polished rice grains
}

\section{Optimización del proceso de extrusión para obtener snack de camarones con arroz partido y granos de arroz pulido}

\author{
Lúcia F. H. Lourenço ${ }^{a}$, Tiago S. Tavares ${ }^{a}$, Eder A. F. Araujo ${ }^{a}$, Rosinelson S. Pena ${ }^{a}$, Maria Regina S. Peixoto Joele ${ }^{b *}$ \\ and Ana Vânia Carvalho ${ }^{\mathrm{c}}$ \\ ${ }^{a}$ Instituto de Tecnologia, Universidade Federal do Pará, Rua Augusto Correa, n.1, 66075-110 Belém, Pará, Brazil; ${ }^{b}$ Departamento de \\ Tecnologia de Alimentos, Instituto Federal de Educação, Ciência e Tecnologia do Pará, Castanhal, Pará, Brazil; ${ }^{\circ}$ Departamento De \\ Agroindústria, Embrapa Amazonia Oriental - Rua Enéas Pinheiro, Belém, Pará, Brazil
}

(Received 1 June 2015; final version received 23 October 2015)

\begin{abstract}
This research studied the effect of thermoplastic extrusion on the expansion index (EI), water absorption index (WAI), water solubility index (WSI), and sensory acceptance (SA) of a snack from rice grits, polished rice grains, and shrimp. A $2^{3}$ factorial design was used with independent variables, temperature in the third extruder zone $\left(63.2-96.8^{\circ} \mathrm{C}\right)$, initial moisture $(106.4-173.6 \mathrm{~g} / \mathrm{kg})$, and shrimp content $(16-$ $184 \mathrm{~g} / \mathrm{kg}$ ), whereas EI, WAI, WSI, and SA were the responses. Through the surface-response methodology, the formulation with $80 \mathrm{~g} / \mathrm{kg}$ shrimp and $130 \mathrm{~g} / \mathrm{kg}$ initial moisture processed at $85^{\circ} \mathrm{C}$ in the third extruder zone was considered optimal. The product had good EI, WAI, and SA, $65.6 \mathrm{~g} / \mathrm{kg}$ moisture, $24.0 \mathrm{~g} / \mathrm{kg}$ lipids, $89.5 \mathrm{~g} / \mathrm{kg}$ proteins, $34.2 \mathrm{~kg} / \mathrm{kg}$ ashes, $72.4 \mathrm{~g} / \mathrm{kg}$ fibers, and $714.3 \mathrm{~g} / \mathrm{kg}$ carbohydrates. The product is an alternative for using rice grit, which has low commercial value, while also fully using the regional shrimp.
\end{abstract}

Keywords: thermoplastic extrusion; rice grit; shrimp snack; polished rice grains

\begin{abstract}
La investigación estudió el efecto de la extrusión termoplástica en el índice de expansión (IE), el índice de absorción de agua (IAA), índice de solubilidad en agua (ISA) y aceptación sensorial (AS) de snack con harina de camarón, arroz partido y granos de arroz pulido. Se utilizó un diseño factorial $2^{3}$, teniendo como variables independientes la temperatura en la tercera zona de la extrusora $\left(63,2-96,8^{\circ} \mathrm{C}\right)$, el contenido de humedad inicial $(106,4-173,6 \mathrm{~g} / \mathrm{kg})$, la proporción de camarón $(16-184 \mathrm{~g} / \mathrm{kg})$ y como respuestas el IE, IAA, ISA y AS. A través de la metodología de superficie de respuesta, la formulación con $80 \mathrm{~g} / \mathrm{kg}$ de harina de camarón y $80 \mathrm{~g} / \mathrm{kg}$ de humedad inicial, procesado a $85^{\circ} \mathrm{C}$ en la tercera zona de la extrusora, fue considerada la condición excelente. El producto presentó buena IE, IAA y AG, $65,6 \mathrm{~g} / \mathrm{kg}$ de humedad, $24,0 \mathrm{~g} / \mathrm{kg}$ de grasa, $89,5 \mathrm{~g} / \mathrm{kg}$ de proteínas, $34,2 \mathrm{~kg} / \mathrm{kg}$ de cenizas, $72,4 \mathrm{~g} / \mathrm{kg}$ de fibras y $714,3 \mathrm{~g} / \mathrm{kg}$ de carbohidratos. El producto obtenido se presenta como una alternativa a la utilización de materias primas de bajo valor comercial, evitando de este modo la generación de residuos y el impacto ambiental.
\end{abstract}

Palabras clave: extrusión termoplástica; arroz partido; camarón regional; arroz pulido

\section{Introduction}

Thermoplastic extrusion is a process in which mechanical action is combined with heat to continuously mix, plasticize, and gellify starch, denatured protein materials, and inactivate enzymes, thus forming new structures (Souza \& Menezes, 2008a, 2008b). It is a highly versatile and efficient technology, with low cost and high productivity, short reaction time, and no waste production (Nabeshima \& Grossmann, 2001). The characteristics of the extruded products depend on the chemical makeup, rheological properties, and physical state of the raw material, as well as the type of extruder and operation conditions. The most important extruder operation parameters are temperature, pressure, and matrix diameter, besides the screw design and retention time (Fellows, 2009).

Extruded snack-like products are mostly cereal based and developed mainly from corn, wheat, and rice. However, rice has a relatively low protein content $(60-80 \mathrm{~g} / \mathrm{kg} \mathrm{db})$ (Walter, Marchezan, \& Avila, 2008) and an amino acid profile that is high in glutamic and aspartic acid, while lysine is the limiting amino acid. Thus, protein additives are needed to ensure nutritional diets (Singh, Majumdar, \& Venkateshwarlu, 2014).

Rice (Oryza sativa, L.) is one of the most widely grown and consumed grains in the world, representing an important source of nutrients. When it is processed, low added-value products are produced such as husk, bran, and broken grains (Hagenimana, Xiaolin Ding, \& Fang, 2006). This is a problem for the rice industry since the value of the rice grits is only one-fifth of that of the whole grain. Broken grains are made into rice flour, a product that has been increasingly used in the food industry mainly because it does not affect the taste of most products. This product is a rich source of starch (approximately $880 \mathrm{~g} / \mathrm{kg}$ ), which, besides its nutritional value, plays an important technological role in processed foods (Sandhu, Singh, \& Kaur, 2004).

Research on extrusion processing of fish muscle started in the 1980s (Choudhury \& Gogoi, 1995). Fish are not only excellent sources of high nutritional value protein but also excellent sources of lipid that contains omega-3 fatty acids, especially eicosapentaenoic acid (EPA) and docosahexaenoic acid (DHA) (Kris-Etherton, Harris, \& Appel, 2002). A number of studies have reported the successful incorporation of fish flesh or fish powder into starch-

*Corresponding author. Email: rjoele@yahoo.com.br 
based materials by extrusion processes to produce nutritious extruded products that were acceptable by consumers (Singh et al., 2014; Suknark, Lee, Eifenmiller, \& Philips, 2001).

Seafood has high protein, minerals, and vitamin content and is easy to digest. For its nutritional value, it is considered one of the most complete foods for humans. Macrobrachium amazonicum is a regional shrimp species from the state of Pará, Brazil, where it is explored through both aquiculture and commercial fishing. It is marketed in natura or industrialized without the cephalothorax or without the cephalothorax or exoskeleton. When shrimp is processed, residues such as heads, shells, and tails are created, which correspond to approximately $700 \mathrm{~g} / \mathrm{kg}$ raw material (Silva, Frédou, \& Rosa Filho, 2007).

To increase the protein content and improve the nutritive value of extruded products, various sources of protein, such as corn, oats, soybeans, rice, beans, fish, and other products, may be added to their formulation (Bassinello et al., 2011; Pansawata et al., 2008; Silva, Assis, Carvalho, \& Simões, 2011; Teba, Ascheri, \& Carvalho, 2009).

Several studies have been carried out using the extrusion process to formulate healthier foods, rich in fibers and other components that rank them as functional foods. Extrusion also allows for diversifying the products that meet consumers' needs, especially regarding health (Carvalho, Vasconcelos, Silva, \& Ascheri, 2009; Souza \& Menezes, 2008b; Souza, Magali Leonel, \& Mischan, 2007). Extrusion-cooked products such as savory snacks or breakfast cereals contain significant calorie amounts. One of the strategic avenues followed by the food industry to reduce the energy density of foods is to increase their content of dietary fiber. In addition to its lower calorie content and the regulation of digestion, dietary fiber has positive effects on cardiovascular health, diabetes, weight management, and on the immune system (Anderson et al., 2009).

Considering the potential for the technological and economical use of M. amazonicum, of rice grits, and of polished rice grains, the goal of this research was to study the effects of thermoplastic extrusion on the technological functional properties and on the sensory acceptance (SA) of an extruded snack.

\section{Materials and methods}

\section{Raw materials}

The shrimp (M. amazonicum), widely produced in the north of Brazil, was provided by Amazonas Indústrias Alimentícias S/A AMASA, and the rice grits (Oryza sativa, L.) were provided by Belém Alimentos Ltda. Polished rice (Oryza sativa, L.) was purchased in a store in the city of Belém, Brazil. The shrimp was stored at $-18^{\circ} \mathrm{C}$, while the rice grits and the polished rice grains were kept at room temperature $\left(25^{\circ} \mathrm{C}\right)$.

\section{Raw material characterization}

The shrimp with the shell was made into flour according to the methodology described by Gonçalves, Nogueira, and Lourenço (2009). Analyses were carried out according to the Association of Official Analytical Chemists (AOAC, 1997) for moisture, ashes, proteins (6.25 conversion nitrogen-to-protein factor for shrimp and 5.95 for rice), and lipids in the shrimp, rice grits, and polished rice grains. Starch content was also determined for the rice grits and polished rice grains (Rickard \& Behn, 1987).

The granulometry of the rice grits, polished rice grains, and shrimp flour was determined according to AOAC (1997) method
965.22 with a set of sieves $(1.40 ; 1.00 ; 0.85 ; 0.71 ; 0.50 \mathrm{~mm})$. Around $50 \mathrm{~g}$ aliquots of the sample underwent vibration for $20 \mathrm{~min}$ in a Bertel magnetic sieve agitator. Next, the sieves were weighed with the material caught and particle size distribution was performed.

\section{Experimental design}

The shrimp snacks were processed with different temperatures at the third zone of the extruder $\left(63.2-96.8^{\circ} \mathrm{C}\right)\left(\mathrm{X}_{1}\right)$, initial moisture $(106.4-173.6 \mathrm{~g} / \mathrm{kg})\left(\mathrm{X}_{2}\right)$, and shrimp content $(16-184 \mathrm{~g} / \mathrm{kg})$ $\left(\mathrm{X}_{3}\right)$. The limits established for the independent variable $\mathrm{X}_{3}$ were defined by preliminary tests in which they ranged the shrimp content. Levels higher than $184 \mathrm{~g} / \mathrm{kg}$ shrimp may hinder product expansion during extrusion, resulting in a negative texture of the final product, which was compact and hard, which is not a satisfactory quality for consumption. The product was optimized through a $2^{3}$ central rotational composite design with 17 trials, with eight linear assays at levels -1 and +1 , six axial tests (one variable at levels $\pm \alpha$ and two at 0 ), and three assays in the central point (three independent variables at level 0) (first four columns of Table 1) (Booth, 1990). The responses evaluated were expansion index $\left(\mathrm{Y}_{1}\right)$, water absorption index $\left(\mathrm{Y}_{2}\right)$, water solubility index $\left(\mathrm{Y}_{3}\right)$, and sensory acceptance $\left(\mathrm{Y}_{4}\right)$. The levels of the variables studied in the experimental design were set after preliminary tests.

In the formulations, the ratio of rice grits to polished rice grains was set at $1: 1$ and $3 \% \mathrm{NaCl}$ were added. The formulations were processed in a single-screw extruder (Labor PQ30, INBRAMAQ, São Paulo, Brazil), with interchangeable configuration and screw, temperature control of the different heating zones, and adjustable screw speed. The temperatures at the first

Table 1. Central rotational composite design for the independent variables $\left(\mathrm{X}_{1}\right.$, temperature at the third extrude zone $\left({ }^{\circ} \mathrm{C}\right) ; \mathrm{X}_{2}$, initial moisture $(\mathrm{g} / \mathrm{kg}) ; \mathrm{X}_{3}$, shrimp content $\left.(\mathrm{g} / \mathrm{kg})\right)$, in its original and coded forms, and experimental outcomes of the extruded product's properties.

Tabla 1. Diseño compuesto rotacional central para las variables independientes $\left(\mathrm{X}_{1}\right.$ temperatura de la tercera zona de la extrusora $\left({ }^{\circ} \mathrm{C}\right) ; \mathrm{X}_{2}$, contenido inicial de humedad $(\mathrm{g} / \mathrm{kg}) ; \mathrm{X}_{3}$, porcentaje de camarones $(\mathrm{g} /$ $\mathrm{kg}$ ), en su forma original y codificada y los resultados experimentales de las propiedades del producto extruido.

\begin{tabular}{lccccccc}
\hline Assay & $\mathrm{X}_{1}$ & $\mathrm{X}_{2}$ & $\mathrm{X}_{3}$ & EI & WAI & WSI & SA \\
\hline 1 & $-1(70)$ & $-1(120)$ & $-1(50)$ & 3.10 & 6.51 & 64.5 & 5.07 \\
2 & $+1(90)$ & $-1(120)$ & $-1(50)$ & 3.05 & 6.51 & 67.1 & 5.00 \\
3 & $-1(70)$ & $+1(160)$ & $-1(50)$ & 2.92 & 6.36 & 123.6 & 2.50 \\
4 & $+1(90)$ & $+1(160)$ & $-1(50)$ & 3.03 & 4.44 & 86.8 & 4.12 \\
5 & $-1(70)$ & $-1(120)$ & $+1(150)$ & 3.48 & 4.79 & 46.0 & 7.00 \\
6 & $+1(90)$ & $-1(120)$ & $+1(150)$ & 3.64 & 6.65 & 58.7 & 6.15 \\
7 & $-1(70)$ & $+1(160)$ & $+1(150)$ & 2.97 & 6.55 & 66.0 & 2.97 \\
8 & $+1(90)$ & $+1(160)$ & $+1(150)$ & 2.80 & 6.59 & 126.9 & 2.12 \\
9 & $-1.68(63.2)$ & $0(140)$ & $0(100)$ & 3.11 & 6.61 & 38.3 & 5.15 \\
10 & $1.68(96.8)$ & $0(140)$ & $0(100)$ & 3.11 & 6.58 & 46.4 & 5.30 \\
11 & $0(80)$ & $-\alpha(106.4)$ & $0(100)$ & 3.65 & 5.85 & 55.1 & 8.25 \\
12 & $0(80)$ & $+\alpha(173.6)$ & $0(100)$ & 2.98 & 6.52 & 55.7 & 4.02 \\
13 & $0(80)$ & $0(140)$ & $-\alpha(16)$ & 2.81 & 6.87 & 59.4 & 2.57 \\
14 & $0(80)$ & $0(140)$ & $+\alpha(184)$ & 3.12 & 6.51 & 53.7 & 6.22 \\
15 & $0(80)$ & $0(140)$ & $0(100)$ & 3.11 & 4.82 & 27.8 & 5.97 \\
16 & $0(80)$ & $0(140)$ & $0(100)$ & 3.13 & 4.33 & 10.0 & 5.92 \\
17 & $0(80)$ & $0(140)$ & $0(100)$ & 3.16 & 4.70 & 36.6 & 6.75 \\
\hline
\end{tabular}

Notes: Values in parenthesis are the original forms of the variables. EI - expansion index; WAI - water absorption index $(\mathrm{kg} / \mathrm{kg} \mathrm{db})$; WSI - water solubility index ( $\mathrm{g} /$ $\mathrm{kg})$; SA - sensory acceptance.

Notas: Los valores en paréntesis son las formas originales de las variables. EI índice de expansión; WAI - índice de absorción del agua ( $\mathrm{kg} / \mathrm{kg}$ bs); WSI - índice de solubilidad del agua $(\mathrm{g} / \mathrm{kg}) ; \mathrm{SA}$ - aceptación sensorial. 
and second extruder zones were kept constant (Zone $1=40^{\circ} \mathrm{C}$; Zone $2=60^{\circ} \mathrm{C}$ ), screw speed was set at $175 \mathrm{rpm}$, average feeding rate was about $290 \mathrm{~g} / \mathrm{min}$, and the circular matrix was set at $3.85 \mathrm{~mm}$. The extrusion conditions were held constant throughout the processing.

After extrusion, all formulations were placed onto stainless steel trays and subjected to complementary drying in a forced airflow drier (DeLeo, Q $314 \mathrm{M} 122$, Brazil) at $60^{\circ} \mathrm{C}$ until moisture reached $60 \mathrm{~g} / \mathrm{kg}$. Next, the product was cooled to room temperature for about $30 \mathrm{~min}$, packed in polyethylene bags, and stored in an airtight plastic recipient until the analyses were carried out.

\section{Characterization of the extruded snack}

The water absorption index (WAI) and the water solubility index (WSI) were determined according to the methodology described by Anderson, Conway, Pfeifer, and Griffin Jr. (1969) and the expansion index (EI), according to Batistuti, Barros, and Arêas (1991). SA was evaluated by 160 tasters, who were potential consumers of the product, by using an acceptance test with a nine-point hedonic scale from 1 (disliked very much) to 9 (liked very much), according to the methodology proposed by Murrey, Delahunty, and Baxter (2001).

Analyses of moisture, ashes, protein, and lipids were performed on the optimized extruded formulation following the methodologies already mentioned. Total dietary fiber analyses were also carried out through the enzymatic/gravimetric method (AOAC, 1997). Color was assessed in a Minolta CR-310 colorimeter with readings from three samples. The results were expressed as $\mathrm{L}^{*}, \mathrm{a}^{*}$, and $\mathrm{b}^{*}$ from the CIELAB system.

\section{Statistical analysis}

The responses of the experimental design underwent pure error analysis of variance (ANOVA) with the aid of the software Statistica Kernel Release 7.1 (StatSoft Inc., 2006, Tulsa, OK, USA) for Windows XP.

\section{Results and discussion}

\section{Physicochemical characterization of the raw materials}

The main component of the polished rice grains $(807.0 \pm 0.1 \mathrm{~g} / \mathrm{kg})$ and the rice grits was starch $(771.3 \pm 1.0 \mathrm{~g} / \mathrm{kg})$, while for the shrimp flour it was proteins $(610.0 \pm 0.2 \mathrm{~g} / \mathrm{kg})$, although this flour had a highly representative amount of mineral residue (ashes) $(260.0 \pm 0.2 \mathrm{~g} / \mathrm{kg})$. The three flours studied - shrimp flour $(32.0 \pm<0.1 \mathrm{~g} / \mathrm{kg})$, rice grits $(7.0 \pm 0.1 \mathrm{~g} / \mathrm{kg})$, and polished rice grains $(5.0 \pm 0.1 \mathrm{~g} / \mathrm{kg})$ - had a low lipid content, which may favor a low-calorie product. The values of the main components of the rice grits are close to those found in the literature, which report lipid contents ranging from 3.0 to $25.3 \mathrm{~g} / \mathrm{kg}$, proteins from 68.3 to $81.3 \mathrm{~g} / \mathrm{kg}$, ashes from 2.2 to $7.4 \mathrm{~g} / \mathrm{kg}$, carbohydrates from 718.1 to $861.6 \mathrm{~g} / \mathrm{kg}$, and fibers from 16.2 to $21.3 \mathrm{~g} / \mathrm{kg}$ (Borges Ascheri, Ascheri, Nascimento, \& Freitas, 2003; Heisler, Antônio, Moura, Mendonça, Granada, 2008; Limberger, Silva, Emanuelli, Comarela, \& Patias, 2008).

The instrumental color parameters indicated the presence of red $\mathrm{a}^{*}(+6.37)$ and yellow $\mathrm{b}^{*}(+23.88)$ in the shrimp flour, attributed to the typical shrimp pigments. In the rice grits, the parameter $b^{*}(+15.60)$ indicated the presence of yellow, attributed to the color of the husk, while the polished rice grains had a greater tendency to white color given the high value of $\mathrm{L}^{*}(90.43)$ and the values of $a^{*}(+0.15)$ and $b^{*}(+4.5)$ close to zero.

The results of the raw material granulometry analysis showed that the shrimp flour had the smallest particle size, with a $94.06 \%$ fraction below $1.00 \mathrm{~mm}$. The rice grits and polished rice grains had the same granulometry profile, with most particles $(98.02 \%$ and $98.66 \%$, respectively) between 0.85 and $1.40 \mathrm{~mm}$.

Ingredient particle size in the mix influences the texture of extruded products, since very fine particles, when moistened, are more able to lump together than larger particles (Booth, 1990; Carvalho, Vasconcelos, Silva, Assis, \& Ascheri, 2010; Riaz, 2002). Finer particles are easily fused, resulting in a sticky mass that is hard to move inside the extruder, while particles below $0.5 \mathrm{~mm}$ can be only partially fused during extrusion, besides tending to break the cell walls of the extruded product, causing a decrease in the expansion rate (Mercier, Linko, \& Harper, 1998).

\section{Results of experimental design}

The results obtained for the dependent variables (responses), along with the independent variables in their original and coded form, are shown in Table 1 (columns 5-8). The result of the analysis of significance of the influence of factors on the EI, WAI, WSI, and SA are summarized in the Pareto graphs (Figure 1), with a 95\% significance level $(p=0.05)$. The estimated effect indicates how much each factor impacts the response studied; the higher its value, the higher the influence of the variable on the response.

Significant $(p \leq 0.05)$ effects were seen for the initial moisture and shrimp content variables (linear $(\mathrm{L})$ and quadratic $(\mathrm{Q})$ ), besides the interaction between these variables, on the extruded product's EI (Figure 1a). Initial moisture (M) and the interaction had effects with negative values, while shrimp content (L) had a positive effect, suggesting that the first two factors caused a reduction, while the third caused an increase in EI response under the conditions studied. On the other hand, initial moisture (Q) had a positive effect while shrimp content (Q) had a negative effect, suggesting that these factors provided a minimum and maximum value, respectively, for the EI response.

Initial moisture was the variable with the greatest effect on EI, where the increase in the variable level caused a reduction in EI. Ding, Ainsworth, Plunkett, Tucker, and Marson (2006) also found that initial moisture was the variable with the greatest effect on density and the expansion of extruded products. According to those authors, the great dependency of density and expansion on moisture may be attributed to its influence on the elastic characteristics of the materials. High moisture values may reduce the dough's elasticity by plasticizing the fused material, resulting in a reduction of the specific mechanical energy with a consequent reduction in jellifying. A similar effect on the EI of the extruded products was also reported by Mendonça, Grossmann, and Verhe (2000).

The positive effect of the shrimp content variable on EI was an important result since it showed that the addition of up to $184 \mathrm{~g} / \mathrm{kg}$ of shrimp flour to the formulation did not limit the product's expansion, which is a desirable characteristic in extruded products. According to Riaz (2002), larger particles tend to break the cell walls of the extruded product, causing a reduction in EI. Additionally increasing protein (shrimp) affects the expansion of the products, while the addition of starch (rice) improves this index (Fernandes, Wang, Ascheri, Oliveira, \& 

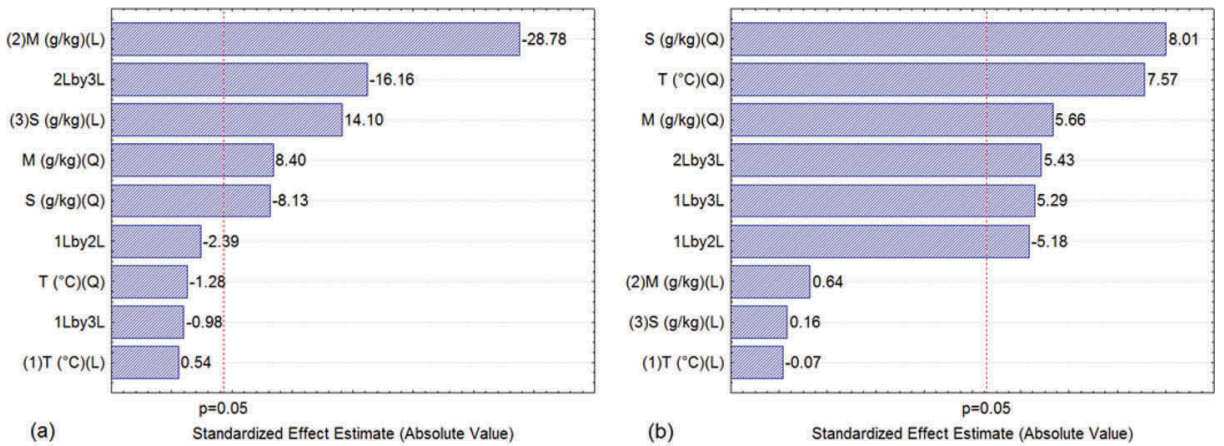

(b)

Standardized Effect Estimate (Absolute Value)
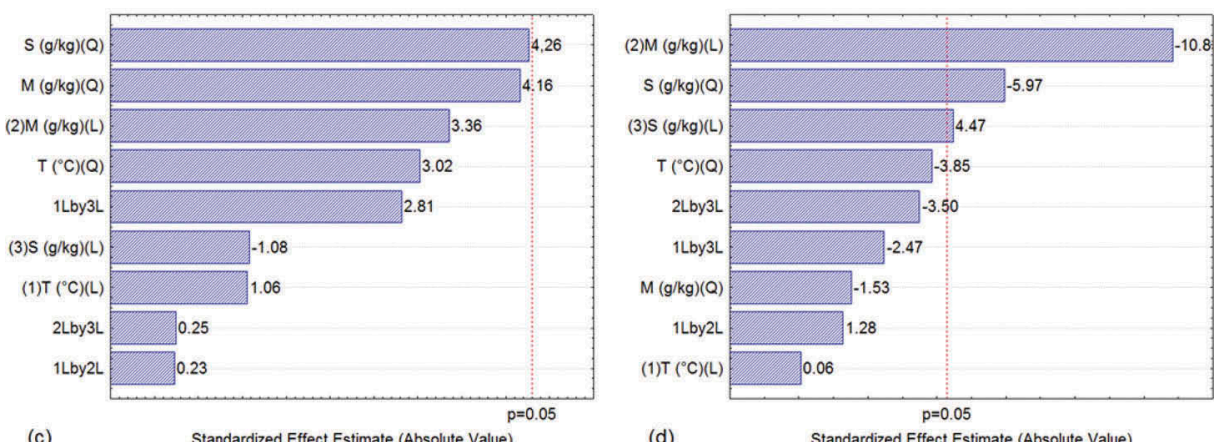

Figure 1. Pareto graph for the standardized effects on the properties: (a) expansion index (EI); (b) water absorption index (WAI); (c) water solubility index (WSI); and (d) sensory acceptance (SA) of the extruded product. T: temperature at the third extruder zone $\left({ }^{\circ} \mathrm{C}\right)$; M: initial moisture $(\mathrm{g} / \mathrm{kg})$; and $\mathrm{S}$ : shrimp content $(\mathrm{g} / \mathrm{kg})$.

Figura 1. Diagrama de Pareto de los efectos estandarizados sobre las propiedades: (a) el índice de expansión (IE), (b) índice de absorción de agua (IAA), (c) índice de solubilidad en agua (ISA) y (d) evaluación sensorial (AS) del producto extruido. T: temperatura de la tercera zona de la extrusora $\left({ }^{\circ} \mathrm{C}\right)$; M: humedad inicial $(\mathrm{g} / \mathrm{kg})$ y S: porcentaje de camarones $(\mathrm{g} / \mathrm{kg})$.

Costa, 2002). On the other hand, this study contributes to demonstrating that protein is an ingredient that can damper the EI of extrudates. Among the formulation components, shrimp flour was the fraction with the largest particles and with protein $(610.0 \pm 0.2 \mathrm{~g} / \mathrm{kg})$ as the main component, while rice grits $(771.3 \pm 1.0 \mathrm{~g} / \mathrm{kg})$ and polished rice grains $(807.0 \pm 0.1 \mathrm{~g} / \mathrm{kg})$ had starch and the main component.

Ilo and Berghofer (1999) added amaranth flour to rice-based shrimp snacks and found an inversely proportional relation between the amaranth content in the formulation and product expansion. Similar results were found by Hsieh, Mulvaneg, Huff, Lue, and Brent (1989) when studying the effect of adding fibers and of the screw speed on the physical characteristics of corn flour-based extruded products. Those authors noticed that the presence of fibers reduces the dough's elasticity and plasticity, thus reducing EI.

After eliminating the parameters with nonsignificant effects on the EI, WAI, and SA variables, ANOVA showed the significance of the regression and the lack of fit, with $95 \%$ confidence $(p \leq 0.05)$, whose results are listed in Table 2. A second-order polynomial model (Equation (1)) was used to represent the effect of the independent variables on the responses.

$$
\begin{aligned}
\text { EI, WAI, and SA }= & \beta_{\mathrm{o}}+\beta_{\mathrm{T}} \mathrm{T}+\beta_{\mathrm{M}} \mathrm{M}+\beta_{\mathrm{S}} \mathrm{S}+\beta_{\mathrm{TT}} \mathrm{T}^{2} \\
& +\beta_{\mathrm{MM}} \mathrm{M}^{2}+\beta_{\mathrm{SS}} \mathrm{S}^{2}+\beta_{\mathrm{TM}} \mathrm{TM} \\
& +\beta_{\mathrm{TS}} \mathrm{TS}+\beta_{\mathrm{MS}} \mathrm{MS}
\end{aligned}
$$

where EI, WAI, and SA are, respectively, the expansion index, water absorption index, and sensory acceptance response
Table 2. Analysis of variance (ANOVA) of the model adjusted to: (a) expansion index (EI); (b) water absorption index (WAI); and (c) sensory acceptance (SA) of the extruded product.

Tabla 2. Análisis de la varianza (ANOVA) del modelo ajustado: (a) índice de expansión (IE); (b) índice de absorción de agua (IAA); y (c) aceptación sensorial (AS) del producto extruido.

Source

$\begin{array}{lllllll}\begin{array}{l}\text { of variation } \\ \text { o }\end{array} & \text { SQ } & \text { GL } & \text { MQ } & \mathrm{F}_{\text {calculated }} & \mathrm{F}_{\text {tabbed }}(\mathrm{p} \leq 0.05) & \mathrm{R}^{2}\end{array}$

(a) Expansion index (EI)

$\begin{array}{lllllll}\text { Regression } & 0.9387 & 5 & 0.1877 & 55.21 & 3.20 & 0.96\end{array}$

$\begin{array}{llll}\text { Residue } & 0.0372 & 11 & 0.0034\end{array}$

$\begin{array}{llll}\text { Lack-of-fit } \quad 0.0359 & 9 & 0.0040\end{array}$

$\begin{array}{llll}\text { Pure error } & 0.0012 & 2 & 0.0006\end{array}$

6.67

19.40

Total $0.9759 \quad 16$

(b) Water absorption index (WAI)

$\begin{array}{llll}\text { Regression } & 11.9680 & 6 & 1.9947\end{array}$

$\begin{array}{lrrr}\text { Residue } & 1.5030 & 10 & 0.1503\end{array}$

$\begin{array}{llll}\text { Lack-of-fit } \quad 1.3720 & 8 & 0.1715\end{array}$

$\begin{array}{llll}\text { Pure error } & 0.1300 & 2 & 0.0650\end{array}$

$\begin{array}{lrr}\text { Total } & 13.4710 & 16\end{array}$

(c) Sensory acceptance (SA)

Regression $38.0262 \quad 4 \quad 9.5066$

$\begin{array}{llll}\text { Residue } & 10.5585 & 12 & 0.8799\end{array}$

Lack-of-fit $\quad \begin{array}{lll}10.1306 & 10 & 1.0131\end{array}$

$\begin{array}{lrrr}\text { Pure error } & 0.4279 & 2 & 0.2140\end{array}$

Total $\quad 48.5847 \quad 16$

$\begin{array}{lll}13.29 & 3.22 & 0.88\end{array}$

$10.80 \quad 3.26$

variables; $\mathrm{T}, \mathrm{M}$, and $\mathrm{S}$ represent the independent variables of temperature at the third extruder zone, initial moisture, and shrimp content, respectively; and the regression coefficients are $\beta_{\mathrm{o}}$ (for the intersection), $\beta_{\mathrm{T}}, \beta_{\mathrm{M}}$, and $\beta_{\mathrm{S}}$ (for the linear terms), $\beta_{\mathrm{TT}}$, 
$\beta_{\mathrm{MM}}$, and $\beta_{\mathrm{SS}}$ (for the quadratic terms), and $\beta_{\mathrm{TM}}, \beta_{\mathrm{TS}}$, and $\beta_{\mathrm{MS}}$ (for the interaction terms).

The model proposed by the regression to represent the EI was the one presented in Equation (2). The values in Table 2 indicate the regression had a coefficient of determination $\left(\mathrm{R}^{2}\right)$ of 0.96 , being considered significant at $95 \%$ confidence $\left(F_{\text {calculated }}>\right.$ $\mathrm{F}_{\text {tabbed }}$ ), which shows the model explained $96 \%$ of the variation in the experimental data. Therefore, since the lack of fit was not significant $(p>0.05)$ and the value of the calculated $\mathrm{F}$ was 17.2 times greater than the tabbed $\mathrm{F}$, the model proposed might be used to describe the EI response.

$$
\begin{aligned}
\mathrm{EI}= & 5.283-0.042 \mathrm{M}+0.027 \mathrm{~S}+1.7 \times 10^{-4} \mathrm{M}^{2}-2.3 \\
& \times 10^{-5} \mathrm{~S}^{2}-1.4 \times 10^{-4} \mathrm{MS}
\end{aligned}
$$

Through Equation (2), contour curves were made for the variable EI, which are shown in Figure 2 and describe the effect of temperature at the third extruder zone, of initial moisture, and of shrimp content on EI. The surfaces clearly showed that low initial moistures and high shrimp content cause an increase in the product's EI, and that temperature did not impact this trend. Mendonça et al. (2000), when assessing the effect of moisture (160-220 g/ kg), of temperature of thermoplastic extrusion $\left(150-190^{\circ} \mathrm{C}\right)$, and of adding corn meal $(180-320 \mathrm{~g} / \mathrm{kg})$ in snack production, found the same effect of the corn meal variable on EI, but also found a linear effect of temperature on the variable, which was not seen in the present research.

Under the conditions studied, the WAI value of the extruded product ranged between 4.33 and $6.87 \mathrm{~kg} / \mathrm{kg}$, within the range found by Mercier et al. (1998) for extruded starch (3$10 \mathrm{~kg} / \mathrm{kg}$ ). The results of the ANOVA of the influence of factors on WAI (Figure 1b) suggested significant effects $(p \leq 0.05)$ of the quadratic terms of the variables of temperature at the third extruder zone $(\mathrm{T})$, initial moisture $(\mathrm{M})$, and shrimp content $(\mathrm{S})$, as well as the interaction $\mathrm{T} \times \mathrm{M}, \mathrm{T} \times \mathrm{S}$, and $\mathrm{M} \times \mathrm{S}$, on the response. The interaction $\mathrm{T} \times \mathrm{M}$ was the only factor that had a negative effect, indicating a decrease in the product's WAI. The other factors had positive effects, indicating a directly proportional relation between the factor and the response, for the linear effects, and the existence of a minimum value, for the quadratic effects.

According to Alvim, Sgarbieri, and Chang (2002), WAI depends on exposing hydrophilic groups (-OH) from the amylose and amylopectin molecules and on the gel-forming ability of these molecules. WAI is related to the ability of the product's components to absorb and hold water. During extrusion, the starch granules undergo jellification and the proteins are denatured. Jellified starch absorbs more water than in its natural state, while the proteins, due to conformational and structural changes, have their hydrophilic/hydrophobic balance affected, which might contribute to either increase or decrease the WAI.

The results of the ANOVA applied only to the factors that have a significant $(p \leq 0.05)$ effect on the WAI response are shown in Table 2. From the results, the coded model was generated to represent the variable (Equation (3)). According to the ANOVA, the adjusted model can be considered significant and predictive with $95 \%$ confidence, since $\mathrm{F}_{\text {calculated }}$ for the regression was 4.1 times higher than $\mathrm{F}_{\text {tabbed. }}$. No lackof-fit was found $(p>0.05)$ and the $\mathrm{R}^{2}$ value of 0.88 shows
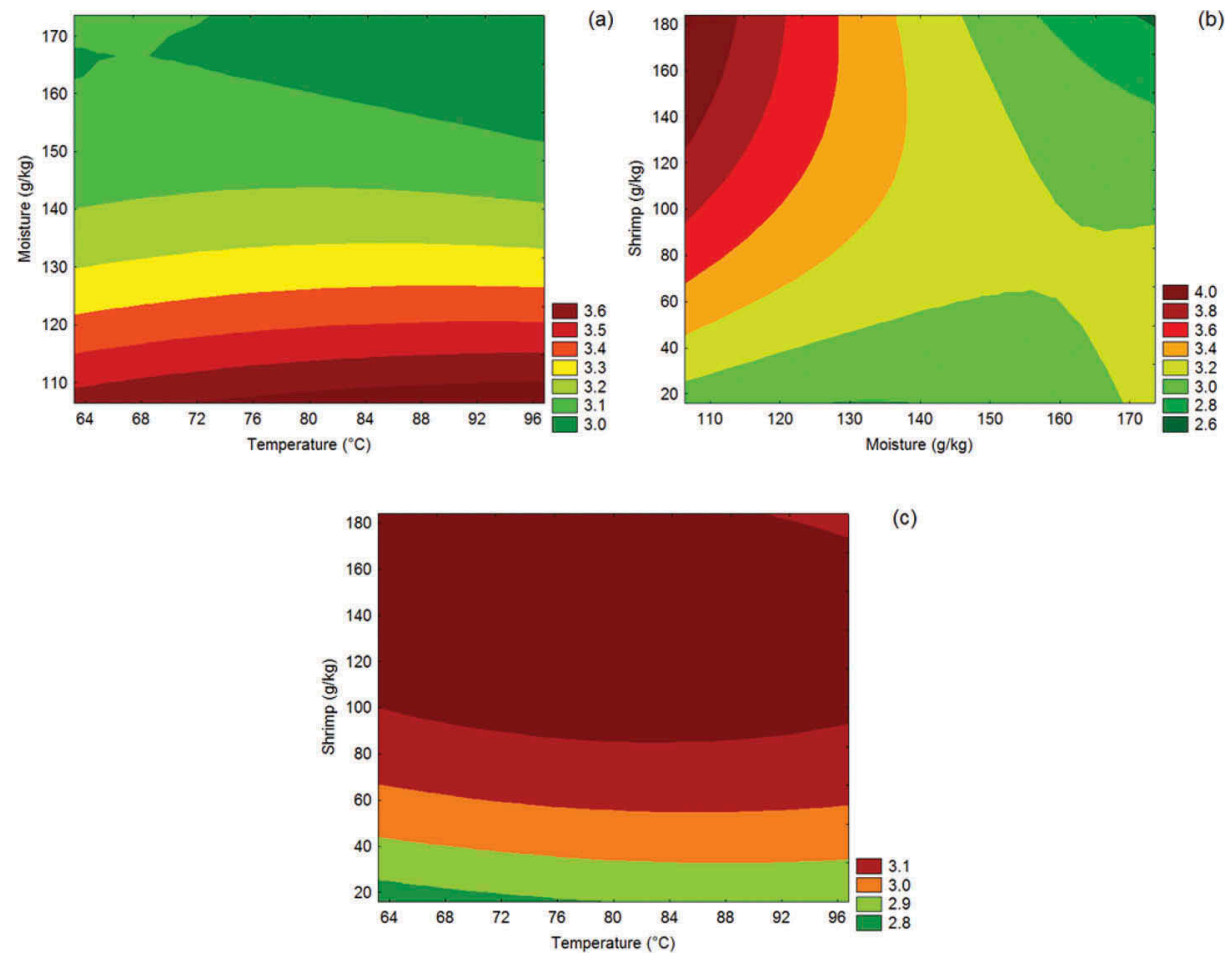

Figure 2. Contour surface showing the effects of process parameters on the expansion index (EI): (a) moisture content and temperature at the third extruder zone at $100 \mathrm{~g} / \mathrm{kg}$ shrimp content; (b) shrimp and moisture contents at $80^{\circ} \mathrm{C}$ in the third extruder zone; and (c) shrimp content and temperature at the third extruder zone at $140 \mathrm{~g} / \mathrm{kg}$ moisture content.

Figura 2. Superficie del contorno que muestra los efectos de los parâmetros del proceso en el índice de expansión (IE): (a) contenido de humedad y temperatura en la tercera zona de la extrusora en $100 \mathrm{~g} / \mathrm{kg}$ de camarón; (b) contenido de camarón y de humedad en $80^{\circ} \mathrm{C}$ en la tercera zona de la extrusora; y (c) contenido de camarón y temperatura en la tercera zona de la extrusora en $140 \mathrm{~g} / \mathrm{kg}$ de humedad. 
that the model explained $88 \%$ of the variation in the data observed.

$$
\begin{aligned}
\mathrm{WAI}= & 4.952+2.8 \times 10^{-3} \mathrm{~T}^{2}+8.5 \times 10^{-4} \mathrm{M}^{2}+1.4 \\
& \times 10^{-4} \mathrm{~S}^{2}-2.9 \times 10^{-3} \mathrm{TM}-3.0 \times 10^{-4} \mathrm{TS} \\
& -1.3 \times 10^{-5} \mathrm{MS}
\end{aligned}
$$

The contour curves generated by Equation (3) are shown in Figure 3, which shows the effect of temperature at the third extruder zone, of initial moisture, and of the shrimp content on WAI. It can be seen that at the lowest initial moisture levels, the product's WAI increased with temperature at the third extruder zone, while for higher moisture levels the temperature had an inverse effect on the response. This behavior can be justified by the fact that the starch jellified absorbs more water than in its natural state (Alvim et al., 2002), and the lower the moisture content, the higher the starch jellifying temperature, which was also reported by Louaer, Meniai, and Grolier (2008).

In Figure 3, it can be seen that for higher shrimp contents in the formulation (protein), the increase in WAI was linked to the increase in initial moisture, with an inversion of the effect of initial moisture for lower shrimp contents. The same correlation was seen for the interaction between the temperature at the third extruder zone and shrimp content. Filli, Nkama, Abubakar, and Jideani (2010), studying the influence of extrusion parameters in soybean and corn flour, reported that legumes can provide increases in WAI, since this is a raw material that has a considerable amount of proteins, which are water-soluble molecules, that contribute to increase the content of components in suspension. WAI is an index that is strongly related to extrusion process moisture and temperature, where these are the main parameters responsible for starch jellifying (Ding et al., 2006). Clerice and El-Dash (2008) and Silva and Ascheri (2009), respectively, found WAI of $7.66 \mathrm{~kg} / \mathrm{kg}$ and $7.76 \mathrm{~kg} / \mathrm{kg}$ in broken rice. These findings suggest that the rice flour had substantially contributed to increase the obtained WAI.

Although Table 1 shows that the WSI of the extruded product ranged from 10.0 to $126.9 \mathrm{~g} / \mathrm{kg}$ for the different formulations, the Pareto graph in Figure 1c suggests that there was no significant $(p>0.05)$ linear or quadratic effect, nor of the interaction among the variables of temperature at the third extruder zone, initial moisture, or shrimp content on the response. In this case, the coefficient of determination $\left(\mathrm{R}^{2}\right)$ suggested that the model explained only $64 \%$ of the variation in the experimental WSI data, which might have contributed to the observed behavior.

Figure 1d shows the Pareto graph of the result of the analysis of significance of the variables on SA to which the extruded shrimp snacks made under different conditions were subjected. According to the ANOVA, significant $(p \leq 0.05)$ effects were found for initial moisture (L) and shrimp content (L, Q) on the SA response. Initial moisture (L) was the parameter with the greatest effect on the response, which was negative, suggesting an indirectly proportional relation with SA. The positive effect of shrimp content (L) suggests that the increase in this variable caused an increase in SA, while the negative effect of the quadratic term of this variable suggests that the extruded products with intermediate shrimp content in the formulation received the highest scores for SA.

The ANOVA results applied after eliminating the parameters with nonsignificant effects on the SA response are shown in Table 2. The model proposed from the results (Equation (4)) had a significant regression with $95 \%$ confidence $\left(\mathrm{F}_{\text {calculated }}>\mathrm{F}_{\text {tabbed }}\right)$, with $\mathrm{R}^{2}$ of 0.88 , which suggests that the model explained $88 \%$ of
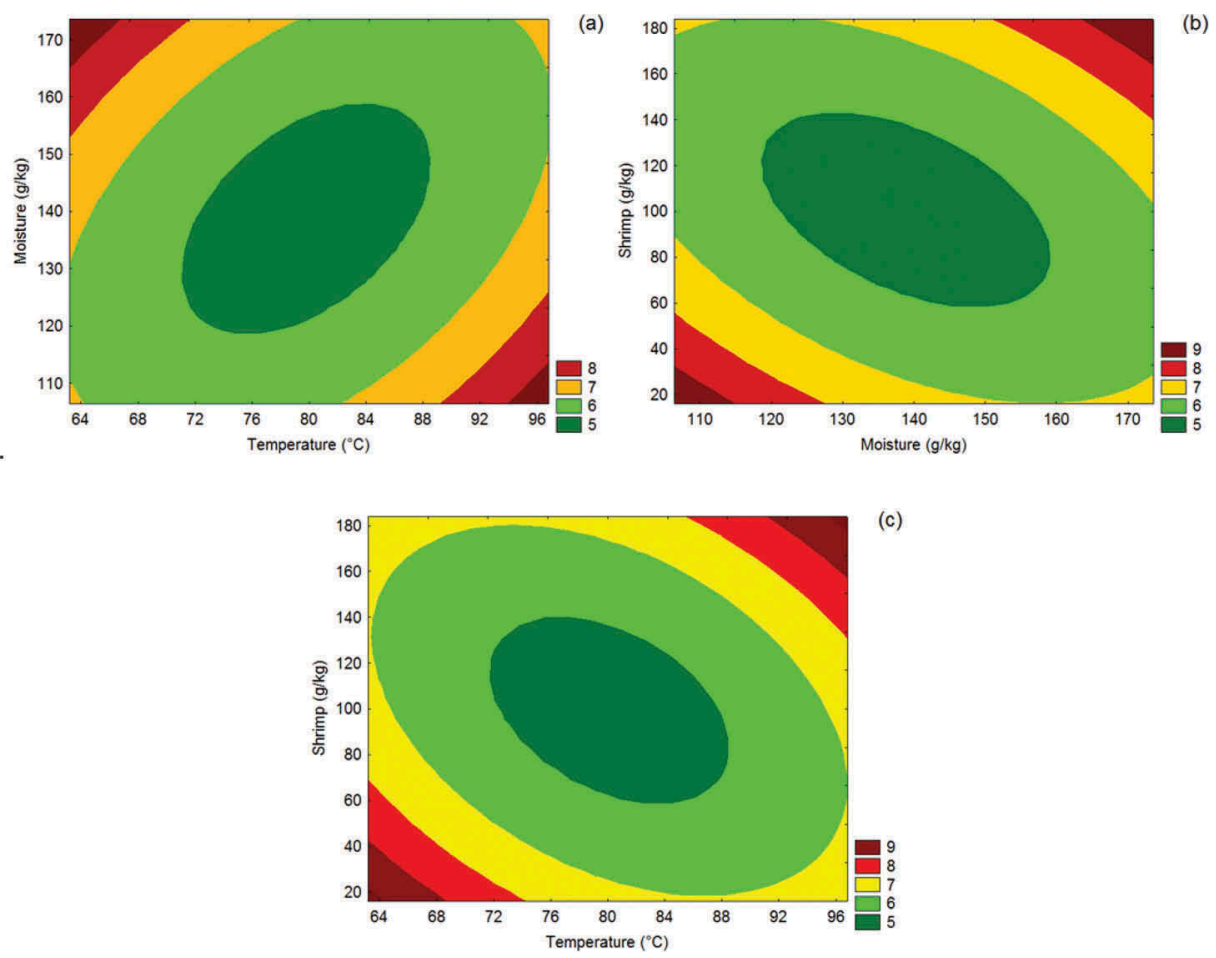

Figure 3. Contour surface showing the effects of process parameters on the water absorption index (WAI). (a) Moisture content and temperature at the third extruder zone at $100 \mathrm{~g} / \mathrm{kg}$ shrimp content; (b) shrimp and moisture contents at $80^{\circ} \mathrm{C}$ in the third extruder zone; and (c) shrimp content and temperature at the third extruder zone at $140 \mathrm{~g} / \mathrm{kg}$ moisture content.

Figura 3. Superficie del contorno que muestra los efectos de los parâmetros del proceso sobre el índice de absorción de agua (IAA): (a) contenido de humedad y temperatura en la tercera zona de la extrusora en $100 \mathrm{~g} / \mathrm{kg}$ de camarón; (b) contenido de camarón y de humedad en $80^{\circ} \mathrm{C}$ en la tercera zona de la extrusora; y (c) contenido de camarón y temperatura en la tercera zona de la extrusora en $140 \mathrm{~g} / \mathrm{kg}$ de humedad. 

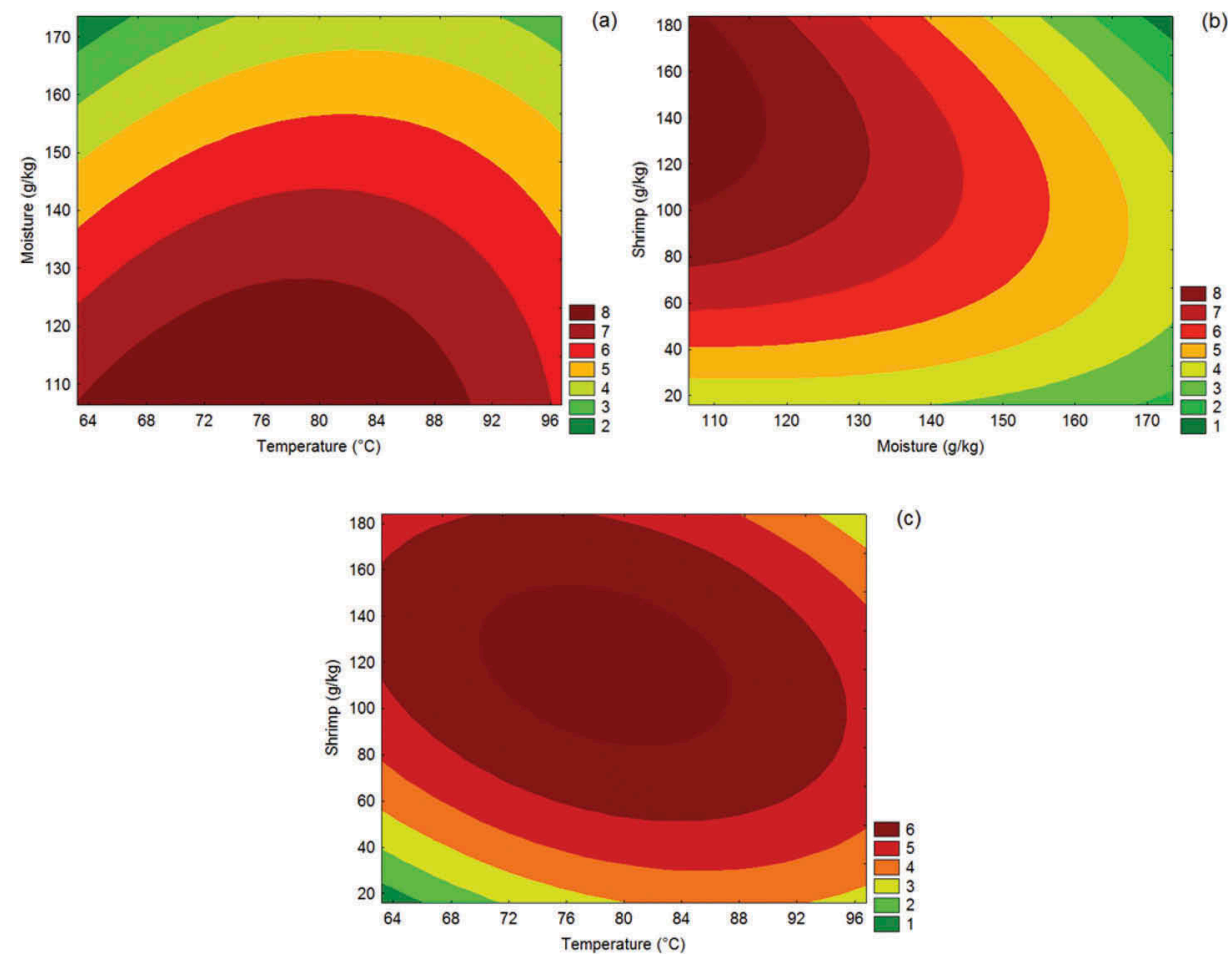

Figure 4. Contour surface showing the effects of process parameters on the sensory acceptance (SA). (a) Moisture content and temperature at the third extruder zone at $100 \mathrm{~g} / \mathrm{kg}$ shrimp content; (b) shrimp and moisture contents at $80^{\circ} \mathrm{C}$ in the third extruder zone; and (c) shrimp content and temperature at the third extruder zone at $140 \mathrm{~g} / \mathrm{kg}$ moisture content.

Figura 4. Superficie del contorno que muestra los efectos de los parâmetros del proceso sobre la aceptación sensorial (AS): (a) contenido de humedad y temperatura en la tercera zona de la extrusora en $100 \mathrm{~g} / \mathrm{kg}$ de camarón; (b) contenido de camarón y de humedad en $80^{\circ} \mathrm{C}$ en la tercera zona de la extrusora; y (c) contenido de camarón y temperatura en la tercera zona de la extrusora en $140 \mathrm{~g} / \mathrm{kg}$ de humedad.

the variation in the experimental data. As the value of $F_{\text {calculated }}$ was only 3.3 times greater than $\mathrm{F}_{\text {tabbed }}$, the model is significant, but not predictive; thus it can only be used as an indicator of trend for the SA response.

$$
\begin{aligned}
\mathrm{SA}= & 11.40-0.068 \mathrm{M}+0.064 \mathrm{~S}-1.2 \times 10^{-5} \mathrm{~T}^{2}-2.6 \\
& \times 10^{-4} \mathrm{~S}^{2}
\end{aligned}
$$

Figure 4 shows the response surfaces generated through Equation (4), which show the variation in SA response for each parameter studied. The surfaces confirm the trends seen in the Pareto graph of Figure 1d. The highest acceptance indices were obtained for the extruded shrimp snacks with intermediate shrimp content and initial moisture from intermediate to low.

\section{Process optimization}

The choice of the optimal process point for obtaining the extruded product was based on the assessment of the results of the assays in the planning (Table 1) and on the response surfaces (Figures 2 to 4). First, SA was observed, next the technology parameters EI and WAI were assessed given that they convey important characteristics to the extruded products. According to the analysis, the condition indicated as the optimal process point was the formulation with $80 \mathrm{~g} / \mathrm{kg}$ shrimp flour, $130 \mathrm{~g} / \mathrm{kg}$ initial moisture, and processed with $85^{\circ} \mathrm{C}$ at the third extruder zone. The choice of formulation was due to some of the most important quality parameters of expanded food products, density and hardness, which are directly related to the desirable crunchy/crispy texture (Berrios, 2011; Patil, Berrios, Tang, \& Swanson, 2007).

The product obtained at the optimal condition had $65.6 \mathrm{~g} / \mathrm{kg}$ $( \pm 0.2)$ moisture, $24.0 \mathrm{~g} / \mathrm{kg}( \pm 0.2)$ lipids, $89.5 \mathrm{~g} / \mathrm{kg}( \pm 0.2)$ proteins, $34.2 \mathrm{~g} / \mathrm{kg}( \pm 0.02)$ ashes, $72.4 \mathrm{~g} / \mathrm{kg}( \pm 2.1)$ dietary fiber, and $714.3 \mathrm{~g} / \mathrm{kg}( \pm 21.5)$ carbohydrate (other than fiber). Carvalho et al. (2012), in a study on the characterization of an extruded snack of rice grits with bean halves, found $112.7 \mathrm{~g} / \mathrm{kg}$ proteins, $0.9 \mathrm{~g} / \mathrm{kg}$ lipids, $32.7 \mathrm{~g} / \mathrm{kg}$ ashes, and $61.6 \mathrm{~g} / \mathrm{kg}$ fibers. The extruded product obtained had high protein content, attributed to the addition of shrimp flour in the formulation, which has six times more protein $(610.0 \pm 0.2 \mathrm{~g} / \mathrm{kg})$ than rice grits $(97.9 \pm 1.0 \mathrm{~g} / \mathrm{kg})$ and polished rice grains $(62.0 \pm 0.3 \mathrm{~g} / \mathrm{kg})$. Therefore, adding shrimp flour to the extruded snack may represent an increase in protein content, as well as the proteins may play an important role in the product's water absorption. Besides the protein value, dietary fiber $(72.4 \mathrm{~g} / \mathrm{kg})$ is unique, due to the shrimp having been used with shell, which can grant the product the status of a high-fiber food (> $60 \mathrm{~g} / \mathrm{kg}$ ) (Brazil, 1998).

\section{Conclusions}

It was possible to develop an extruded product with high protein $(89.5 \mathrm{~g} / \mathrm{kg})$ and fiber $(72.4 \mathrm{~g} / \mathrm{kg})$ content, EI, WAI, and SA appropriately by using $80 \mathrm{~g} / \mathrm{kg}$ regional shrimp flour, with an initial moisture of $130 \mathrm{~g} / \mathrm{kg}$, and at a temperature of $85^{\circ}$ $\mathrm{C}$ at the third extruder zone. The product obtained is an alternative for using rice grit, which has low commercial value and little industrial use, while also fully using the regional shrimp, 
thus avoiding waste production and a possible environmental impact.

\section{Disclosure statement}

No potential conflict of interest was reported by the authors.

\section{Funding}

This study received financial support from FINEP/SEBRAE, PROPESP (Pró-reitoria de Pesquisa), and FAPESPA (Fundação Amazônia Paraense de Amparo à Pesquisa).

\section{References}

Alvim, I. D., Sgarbieri, V. C., \& Chang, Y. K. (2002). Desenvolvimento de farinhas mistas extrusadas à base de farinha de milho, derivados de levedura e caseína. Ciência E Tecnologia de Alimentos, 22, 170176. doi:10.1590/S0101-20612002000200012

Anderson, J. W., Baird, P., Davis, R. H., Jr., Ferreri, S., Knudtson, M. Koraym, A., ... Williams, C. L. (2009). Health benefits of dietary fiber. Nutrition Reviews, 67(4), 188-205. doi:10.1111/nure.2009.67.issue-4

Anderson, R. A., Conway, H. F., Pfeifer, V. V., \& Griffin, E. L., Jr. (1969). Gelatinization of corn grits by roll and extrusion cooking. Cereal Science Today, 14, 4-7.

AOAC. (1997). Official methods of analysis of the Association of Official Analytical Chemists (16th ed.). Washington, DC: Author.

Bassinello, P. Z., Freitas, D. G. C., Ascheri, J. L. R., Takeiti, C. Y., Carvalho, R. N., Koakuzu, S. N., \& Carvalho, A. V. (2011). Characterization of cookies formulated with rice and black bean extruded flours. Procedia Food Science, 1, 1645-1652. doi:10.1016/j.profoo.2011.09.243

Batistuti, J. P., Barros, R. M. C., \& Arêas, J. A. G. (1991). Optimization of extrusion cooking process for chickpea (Cicer arietinum, L.) defatted flour by response surface methodology. Journal Food Science, 56, 1695-1698. doi:10.1111/j.1365-2621.1991.tb08673.x

Berrios, J. (2011). Extrusion processing of commercial legume pulses. In M. Maskan \& A. Altan (Eds.), Advances in food extrusion technology (pp. 209-236). Boca Raton, FL: CRC press.

Booth, R. G. (1990). Snack food (3th ed.). New York: Van Nostrand Reinhold.

Borges, J. T. S., Ascheri, J. L. R., Ascheri, D. R., Nascimento, R. E., \& Freitas, A. S. (2003). Propriedades de cozimento e caracterização físico química de macarrão pré-cozido à base de farinha integral de quinoa (Chenopodium quinoa, Willd) e de farinha de arroz (Oryza sativa, L) polido por extrusão termoplástica. Boletim Do CEPPA, 21, 303-322.

Brazil. (1998). Ministério da Saúde. Agência Nacional de Vigilância Sanitária. Portaria $n^{\circ}$. 27, de 13 de janeiro de 1998. Dispõe sobre a identidade e as características mínimas de qualidade a que devem obedecer os alimentos que utilizarem a informação nutricional complementar. <http://www.anvisa.gov.br/legis/portarias/27_98.htm.> [accessed Mar 07 2013]

Carvalho, A. V., Bassinello, P. Z., Mattietto, R. A., Carvalho, R. N., Rios, A. O., \& Seccadio, L. L. (2012). Processamento e caracterização de snack extrudado a partir de farinhas de quirera de arroz e de bandinha de feijão. Brazilian Journal of Food Technology, 15, 72-83. doi:10.1590/S1981-67232012000100008

Carvalho, A. V., Vasconcelos, M. A. M., Silva, P. A., \& Ascheri, J. L. R. (2009). Produção de snacks de terceira geração por extrusão de misturas de farinhas de pupunha e mandioca. Brazilian Journal Food Technology, 12, 277-284. doi:10.4260/BJFT2009800900022

Carvalho, A. V., Vasconcelos, M. A. M., Silva, P. A., Assis, G. T., \& Ascheri, J. L. R. (2010). Caracterização tecnológica de extrusados de terceira geração à base de farinhas de mandioca e pupunha. Ciencia E Agrotecnologia, 34(4), 995-1003. doi:10.1590/S141370542010000400028

Choudhury, G. S., \& Gogoi, B. K. (1995, November). High moisture extrusion: Possibilities and prospects. Paper presented at the 4th Conference of Food Engineering, Chicago, IL.

Clerice, M. T. P. S., \& El-Dash, A. A. (2008). Características tecnológicas de farinhas de arroz pré-gelatinizadas obtidas por extrusão termoplástica. Ciência E Agrotecnologia, 32, 1543-1550. doi:10.1590/S1413-70542008000500028
Ding, Q., Ainsworth, P., Plunkett, A., Tucker, G., \& Marson, H. (2006). The effect of extrusion conditions on the functional and physical properties of wheat-based expanded snacks. Journal of Food Engineering, 73, 142-148. doi:10.1016/j.jfoodeng.2005.01.013

Fellows, P. J. (2009). Food processing technology: Principles and practice (3rd ed., pp. 294-308). Boca Raton, FL: CRC Press.

Fernandes, M. S., Wang, S. H., Ascheri, J. L. R., Oliveira, M. F., \& Costa, S. A. J. (2002). Produtos extrusados expandidos de misturas de canjiquinha e soja para uso como petiscos. Pesquisa Agropecuária Brasileira, 37, 1495-1501. doi:10.1590/S0100204X2002001000018

Filli, K. B., Nkama, I., Abubakar, U. M., \& Jideani, V. A. (2010). Influence of extrusion variables on some functional properties of extruded millet-soybean for the manufacture of 'fura': A Nigerian traditional food. African Journal of Food Science, 4, 342-352.

Gonçalves, A. A., Nogueira, W. M., \& Lourenço, L. F. H. (2009). Aproveitamento do descarte do processamento da piramutaba (Brachyplatystoma vaillantii) e do camarão-rosa (Farfantepenaeus subtilis) na produção de salsicha sabor camarão. Boletim Do Instituto de Pesca, 35, 623-635.

Hagenimana, A., Xiaolin Ding, X., \& Fang, T. (2006). Evaluation of rice flour modified by extrusion cooking. Journal of Cereal Science, 43, 38-46. doi:10.1016/j.jcs.2005.09.003

Heisler, G. E. R., Antônio, G. A., Moura, R. S., Mendonça, C. R. B., \& Granada, G. G. (2008). Viabilidade da substituição da farinha de trigo pela farinha de arroz na merenda escolar. Alimentos E Nutrição, 19, 299-306.

Hsieh, F., Mulvaneg, S. S., Huff, H. E., Lue, S., \& Brent, J. (1989). Effect of dietary fiber and screw speed on some extrusion processing and products variables. Lebensmittel Wissenschaft und Technologie, 22, 204-207.

Ilo, S., \& Berghofer, E. (1999). Kinetics of colour changes during extrusion cooking of maize grits. Journal of Food Engineering, 39, 73-80. doi:10.1016/S0260-8774(98)00148-4

Kris-Etherton, P. M., Harris, W. S., \& Appel, L. J. (2002). Fish consumption, fish oil, omega-3 fatty acids, and cardiovascular disease. Circulation, 106, 2747-2757. doi:10.1161/01.CIR.0000038493.65177.94

Limberger, V. M., Silva, L. P., Emanuelli, T., Comarela, C. G., \& Patias, L. D. (2008). Modificação química e física do amido de quirera de arroz para aproveitamento na indústria de alimentos. Química Nova, 31, 84-88. doi:10.1590/S0100-40422008000100018

Louaer, W., Meniai, A. H., \& Grolier, J. P. E. (2008). Thermal analysis of the influence of water content on glass transitions. Journal Thermal Analysis and Calorimetry, 93, 605-610. doi:10.1007/s10973-008-9071-6

Mendonça, S., Grossmann, M. V. E., \& Verhe, R. (2000). Corn bran as a fibre source in expanded snacks. Lebensmittel Wissensechaft und Technologie, 33, 2-8. doi:10.1006/fstl.1999.0601

Mercier, C., Linko, P., \& Harper, J. M. (1998). Extrusion cooking (3th ed.). St. Paul: American Association of Cereal Chemists.

Murrey, J. M., Delahunty, C. M., \& Baxter, I. A. (2001). Descriptive sensory analysis: Past, present and future. Food Research International, 34, 461-471. doi:10.1016/S0963-9969(01)00070-9

Nabeshima, E. H., \& Grossmann, M. V. E. (2001). Functional properties of pregelatinized and cross-linked cassava starch obtained by extrusion with sodium trimetaphosphate. Carbohydrate Polymers, 45, 347-353. doi:10.1016/S0144-8617(00)00273-3

Pansawata, N., Jangchuda, K., Jangchuda, A., Wuttijumnonga, P., Saaliac, F. K., Eitenmillerb, R. R., \& Phillips, R. D. (2008). Effects of extrusion conditions on secondary extrusion variables and physical properties of fish, rice-based snacks. LWT - Food Science and Technology, 41, 632-641. doi:10.1016/j.lwt.2007.05.010

Patil, R. T., Berrios, J. D. J., Tang, J., \& Swanson, B. G. (2007). Evaluation of methods for expansion properties of legume extrudates. Applied Engineering in Agriculture, 23, 777-783. doi: $10.13031 / 2013.24044$

Riaz, M. N. (2002). Extruders in food applications. Boca Raton: USA: CRC Press.

Rickard, J. E., \& Behn, K. R. (1987). Evaluation of acid and Enzyme hydrolytic methods for the determination of cassava starch. Journal of the Science of Food and Agriculture, 41, 373-379. doi:10.1002/ (ISSN)1097-0010

Sandhu, K. S., Singh, N., \& Kaur, M. (2004). Characteristics of the different corn types and their grain fractions: Physicochemical, thermal, morphological, and rheological properties of starches. Journal of Food Engineering, 64, 119-127. doi:10.1016/j. jfoodeng.2003.09.023 
Silva, M. C. N., Frédou, F. L., \& Rosa Filho, J. S. (2007). Estudo do crescimento do camarão Macrobrachium amazonicum (Heller, 1862) da ilha de Combú, Belém, estado do Pará. Amazônia: Cia. \& Desenvolvimento, 2, 85-104.

Silva, P. A. G., Assis, T., Carvalho, A. V., \& Simões, M. G. (2011). Desenvolvimento e caracterização de cereal matinal extrudado de mandioca enriquecido com concentrado proteico de soro de leite. Brazilian Journal of Food Technology, 14(4), 260-266. doi:10.4260/ BJFT2011140400031

Silva, R. F., \& Ascheri, J. L. R. (2009). Extrusão de quirera de arroz para uso como ingrediente alimentar. Brazilian Journal of Food Technology, 12, 190-199. doi:10.4260/bjft2009800900012

Singh, K. R., Majumdar, R. K., \& Venkateshwarlu, G. (2014). Optimum extrusion-cooking conditions for improving physical properties of fish-cereal based snacks by response surface methodology. Journal of Food Science and Technology, 51(9), 1827-1836. doi:10.1007/ s13197-012-0725-9

Souza, L. B., Magali Leonel, M., \& Mischan, M. M. (2007). Efeito dos parâmetros de extrusão nas propriedades físicas de extrusados de misturas de fécula de mandioca e polpa cítrica. Alimentos \& Nutrição, 18, 83-91.

Souza, M. L., \& Menezes, H. C. (2008a). Extrusão de misturas de castanha do Brasil com mandioca. Ciência \& Tecnologia de Alimentos, 28, 451-462. doi:10.1590/S0101-20612008000200029

Souza, M. L., \& Menezes, H. C. (2008b). Otimização do processo de extrusão termoplástica da mistura castanha do Brasil com farinha de mandioca. Ciência \& Tecnologia De Alimentos, 28, 659-667. doi:10.1590/S0101-20612008000300023

Suknark, K., Lee, J., Eifenmiller, R. R., \& Philips, R. D. (2001). Sability of tocopherols and retinyl palmitate in snack extrudates. Sensory and Nutritive Qualities of Food, 66(6), 897-902.

Teba, C. S., Ascheri, J. L. R., \& Carvalho, C. V. P. (2009). Efeito dos parâmetros de extrusão sobre as propriedades de pasta de massas alimentícias pré-cozidas de arroz e feijão. Alimentos E Nutrição, 20, 411-426.

Walter, M., Marchezan, E., \& Avila, L. A. (2008). Arroz: Composição e características nutricionais. Ciência Rural, 38, 1184-1192. doi:10.1590/S0103-84782008000400049 